\title{
Falando aos vivos e aos mortos: a "Oda a Julián del Casal", de Lezama Lima ${ }^{1}$
}

JAMES IRBY

"Where the dead are simply dead, the living are in some sense already dead as well. Conversely, where the afterlife of the dead receives new life, the earth as a whole receives a new blessing."

(Robert Pogue Harrison, The Dominion of the Dead)

"...for the poet is representative. He stands among partial men for the complete man, and apprises us not of his wealth, but of the commonwealth."

(Ralph Waldo Emerson, “The Poet”)

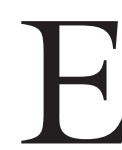

STE COMENTÁRIO ao notável poema de Lezama Lima, “Oda a Julián del Casal", detém-se sobre o modo como seis de seus principais atributos textuais - suas apóstrofes, os motivos verbais recorrentes, a obscuridade, os motivos históricos reconhecíveis, seus tempos verbais, bem como suas alusões míticas - interagem de forma a produzir um efeito retórico determinado. Julián del Casal (Cuba, 1863-1893) é atualmente considerado um dos mais importantes poetas hispano-americanos de seu tempo. Lezama, por seu turno, compôs seu poema em 1963, durante a celebração do centenário de nascimento de Casal. ${ }^{2}$

Como as datas sugerem, Casal foi contemporâneo de Cruz e Sousa e Olavo Bilac, e sua poesia comparte com a deles certos traços que, no Brasil, são classificados como "parnasianos" e "simbolistas", mas que no mundo hispânico são agrupados sob a rubrica do "modernismo". Entre seus poemas mais característicos, estão os dez sonetos da série intitulada "Mi museo ideal" (em seu livro Nieve, de 1892), todos inspirados pelas pinturas de Gustave Moreau, com quem Casal se correspondeu nos últimos anos de sua vida. Quando de sua morte prematura - como Cruz e Sousa, vítima de tuberculose -, Casal começara a ganhar uma fama modesta fora de Cuba, graças em parte ao entusiástico reconhecimento de seu mais viajado e aclamado contemporâneo, o nicaraguense Rubén Darío, de quem ele se tornara amigo durante uma visita desse a Havana, em 1892.

Em sua ardente homenagem póstuma a Casal, Darío (1950, p.693) escreveu algo que, de uma forma ou outra, marcaria por muitos anos a recepção 
do poeta cubano, dentro e fora da ilha: "Casal... é um ser exótico..., [um] portentoso e desventurado sonhador que apareceu, por capricho do destino, em um tempo e um país onde viveria... martirizado e seria sempre estrangeiro". Embora a intenção de Darío com tal caracterização fosse louvar a devoção de Casal a seus ideais estéticos, ela terminou por transformar-se em um hostil lugarcomum por meio do qual outros veriam Casal como um alienado, um mero imitador de poetas franceses.

Lezama, cujo centenário de nascimento se celebra neste ano de 2010, via Casal de forma diferente. Já em 1941, em seu ensaio "Julián del Casal”, ${ }^{3}$ e como extensão de sua própria busca por uma poesia de validade universal que ao mesmo tempo incorporasse a essência de lo cubano, Lezama começara a reavaliar Casal como um poeta autêntico, reconhecendo-lhe as tonalidades cubanas. Duas linhas na argumentação daquela longa e elaborada vindicação de Lezama devem ser notadas. Uma delas prenuncia momentos da "Oda...", percebendo como passagens da poesia supostamente "exótica" de Casal estão em consonância com as circunstâncias mais imediatas de sua vida. A outra prefigura certos traços do livro de Lezama, La expresión americana, ${ }^{4} \mathrm{em}$ que se defende uma leitura mais cuidadosa dos "epígonos" latino-americanos, ressaltando não as modas e os modelos estrangeiros que eles seguiriam, mas sim as conquistas de sua própria escrita em meio à luta por uma expressão na América Latina.

Como já notado antes, Lezama compôs a sua “Oda...” em 1963, durante a celebração do centenário de Casal. Mas é também importante lembrar que tal se deu imediatamente após a Crise dos Mísseis e a tentativa frustrada de invasão na Baía dos Porcos. Em outras palavras, era ainda tempo de um virtual estado de guerra, que gerava em Cuba um envolvente e polarizado clima retórico de slogans, ordens, exortações e anátemas, em flagrante contraste com o poema de Lezama, que desenvolve um tipo diverso de retórica, postulando um espaço coletivo de natureza bastante diferente.

O primeiro atributo do poema a que me refiro é o uso das apóstrofes. De imediato, ele se abre com verbos no imperativo, que falam sucessivamente a dois grupos de destinatários no plural - "ustedes" e "vosotros" -, gentilmente rogando-lhes que permitam a "ele" regressar, para revelar-se:

Déjenlo, verdeante, que se vuelva;

permitidle que salga de la fiesta...

O poema todo é estruturado em torno de uma série de apóstrofes, que se estendem daí ao final. Entretanto, à medida que se desenvolvem, as apóstrofes mudam de destinatário. As primeiras quatro estrofes são dirigidas àquele "vós", no plural. Mas no verso 63 , logo no início da quinta estrofe, o poema subitamente passa a dirigir-se a um "tu", singular: "Las formas en que utilizaste tus disfraces...". 
Esse "tu" é evidentemente o "ele" cujo regresso os versos iniciais haviam rogado que se permitisse, e esse mesmo "tu" será o destinatário ao longo de quase todo o restante do poema, até que cheguemos aos três versos finais, onde a forma de interpelar no plural retorna, quando o "ele" é mencionado pela última vez: "Permitid que se vuelva, ya nos mira...".

Qualquer enunciação dirigida a um "tu" implica necessariamente um "eu", ou "nós", como sua fonte, ainda quando um pronome na primeira pessoa não é utilizado. A voz desse poema jamais diz "eu”. Contudo, a partir do verso 61, apenas dois versos antes que aquele "tu" singular seja evocado pela primeira vez, a voz do poema começa a falar como um "nós":

\section{Su tos alegre sigue ordenando el ritmo}

de nuestra crecida vegetal...

E assim segue, utilizando a primeira pessoa do plural até o fim. É como se aquele "nós" tivesse que explicitar-se para que o "ele" se torne um "tu". Um dos principais recursos retóricos nesse poema é a instância à audiência para que permita ao "ele" regressar do lugar onde esteve, para vir ao(s) espaço(s) que o poema imediatamente começa a caracterizar em seus próprios termos, ao mesmo tempo que vai caracterizando a natureza do "ele", de modo a colocar, por meio dessas mesmas caracterizações, "ele" e "nós" em uma relação peculiar. Uma relação, como veremos, por meio da qual supõe-se que o "ele", que se torna um "tu", age em "nosso" nome, representando-nos numa esfera que terá dimensões propriamente míticas, ainda que as dimensões históricas jamais se percam de vista. Parte desse processo, é claro, é a maneira como o leitor também sente que é a ele que se fala por meio dessa sucessão de vários "tu" - uma sucessão que vai de uma pluralidade neutra a uma singularidade bastante específica. (A propósito, daqui por diante refiro-me a esse "ele" que se torna um "tu" como "o sujeito do poema" - sujeito que é algumas vezes seu protagonista, outras seu destinatário.)

O segundo atributo do poema sobre o qual chamo a atenção começa a aparecer também no início: o uso de certos motivos verbais recorrentes, que passam por variações ou recombinações, algumas das quais retornarão em tocantes configurações musicais - seja uma simples palavra, seja toda uma frase - que se estendem, como as apóstrofes, pelo poema todo. (Por "musicais", refiro-me não a algo agradável de ouvir, mas sim a algo rico em ressonâncias semânticas moduladas.) Por exemplo, o motivo da cor verde, introduzida com uma imediata variação na estrofe de abertura, como primeira caracterização do sujeito cujo regresso o poema reclama:

Déjenlo, verdeante, que se vuelva, permitidle que salga de la fiesta a la terraza donde están dormidos. A los dormidos los cuidará quejoso, 
fijándose como se agrupa la mañana belada.

La errante chispa de su verde errante,

trazará circulos frente a los dormidos

de la terraza...

"Verdeante", como adjetivo semiparticipial derivado do verbo "verdear", significa a ação de tornar-se verde ou de tornar outras coisas verdes, com conotações fortes remetendo à vegetação ou à mudança de estações. A próxima ocorrência de tal motivo, como no caso do substantivo "verde", acontece junto a outro semiparticípio ativo, "errante", do verbo "errar", cujos significados o poema desenvolverá: errante como aquele que erra, vagabundo, multívago, mas também como aquele que desobedece. A junção de "verde" e "errante" não deixa de estar relacionada ao fato de que "verde" adquirirá outras conotações quando aparecer novamente ao longo do poema. Mais à frente, ele se tornará também "el verde de la muerte" (v.142).

Dois outros motivos recorrentes introduzidos nesses primeiros versos são a "terraza" e aqueles "dormidos" nela. Nesse caso, não se trata de uma qualidade ou um traço recorrentes, mas sim de um lugar recorrente, associado a pessoas, ou atores, igualmente recorrentes. O poema jamais esclarecerá quem são esses “dormidos”, mas eles retornarão sempre em estreita conexão com o sujeito, como de fato aparecem no início, quando se prevê que o sujeito "los cuidará quejoso", uma sentença a que voltaremos logo em seguida. A “terraza”, por sua vez, será mais à frente igualada a outro espaço: "las profundidades", "el valle de Proserpina", isto é, o mundo dos mortos. Note-se também que o significado básico de "frio", designado pelo adjetivo em "la mañana helada", também reaparecerá, desdobrando-se em efeitos diversos, primeiramente como "nieve", e então, mais insistentemente, como "frío", especialmente, como veremos, na quarta estrofe (v.44-62). E, de fato, mais ao fim do poema, "terraço" e "frio" vão fundir-se em “terraza helada” (v.191).

O terceiro atributo do poema, também exemplificado imediatamente naquela estrofe inicial, é a peculiar obscuridade da linguagem, evidenciada pelo conjunto provocadoramente misterioso de traços emprestados àquele sujeito que emerge. As apóstrofes apontam diretamente, ou mesmo parecem produzir, um tipo de narrativa: uma cena em que ele e outros personagens e coisas interagem. Ainda assim, à medida que detalhes e gestos vão se acumulando rapidamente, não chegam a formar uma simples estória reconhecível, parecendo, ao invés, combinar pequenas porções de diferentes estórias, diferentes situações, que implicam diferentes tipos de conexão entre si. O leitor poderia perguntar-se por que não mencionei, logo no início, esse atributo do poema; afinal, a obscuridade pode muito bem ser sua característica mais imediata e impressionante. Entretanto, minha intenção foi, em primeiro lugar, chamar atenção sobre algumas de suas mais notáveis recorrências, aquelas que o atravessam desde o início. Tais recorrências oferecem um contexto introdutório bastante útil para compreender 
o poema em sua obscuridade, que tem múltiplos aspectos, dentre os quais se distingue o seu caráter sequencial, narrativo, por natureza causal. Ao aproximarnos da obscuridade por esse ângulo, podemos detectar o seu papel funcional, mais que meramente hermético. Isto é, podemos ver como ela funciona no texto, no lugar de vê-la como o resultado de algum código oculto.

Observemos novamente o que o sujeito faz depois de seu permitido regresso. Ou melhor, o que o poema inicialmente diz, usando o futuro, que o sujeito fará, como que prevendo ações que o poema mesmo, em seu curso, deverá confirmar ou não:

A los dormidos los cuidará quejoso, fijándose como se agrupa la mañana helada.

La errante chispa de su verde errante, trazará circulos frente a los dormidos de la terraza, la seda de su solapa escurre el agua repasada del tritón y otro tritón sobre su espalda en polvo.

É impressionante aqui, e nos versos imediatamente anteriores, como tantos personagens e coisas se sucedem uns aos outros tão rapidamente, por meio de tão próxima interação física, e ainda assim, ao mesmo tempo, numa instabilidade centrífuga: dentro da casa, fora, festa, sono, ação, solicitude, queixas, lapela, arredores percebidos desde os próprios arredores, uma manhã gelada que parece invadida por uma faísca girando em círculos mágicos, pela água através da qual se movem míticos tritões e, ainda, pela poeira! Que tipo de sujeito é esse que o poema convoca? Quais são seus poderes enquanto ele se move por meio de vestígios dos quatro elementos (fogo, água, ar, terra)? Tão dinâmico, tão híbrido... Então, como parte da recorrente apóstrofe que encerra a estrofe (v.11-12), vem essa caracterização ainda mais estranha (que regressará, para concluir o poema):

\section{Dejadlo que se vuelva, mitad ciruelo \\ y mitad piña laqueada por la frente.}

Aqui, nosso sujeito assume momentaneamente o aspecto de uma coisa, um objeto compósito, como se a ameixeira e o abacaxi tivessem sido enxertados e, o que é mais incrível, lacados, como num trabalho de laqueador! Note-se, também, a combinação de motivos asiáticos (ameixeira, o trabalho de laqueação) e um motivo americano e tropical (abacaxi).

Uma curiosa luz será retroativamente lançada sobre essa complexa figuração, pela abertura da próxima estrofe, que de novo repete a apóstrofe. Mas antes ainda de observá-la, é importante identificar, como algo a essa altura particularmente relevante, um quarto atributo do poema, que é como o anverso da obscuridade de que falávamos há pouco. Refiro-me ao tratamento que o poema dá à possibilidade de reconbecimento dos motivos históricos. Afinal de contas, essa 
é uma ode à figura histórica cujo nome aparece no título: será que, em algum momento, o corpo do poema alude àquela figura em termos que um leitor médio poderia identificar? A resposta é: apenas gradualmente, apenas obliquamente $\mathrm{e}$, ainda assim, apenas em termos que somente leitores bem informados sobre a escrita e as circunstâncias pessoais de Casal poderiam reconhecer.

É verdade que alguns contemporâneos de Casal diziam que ele tinha olhos verdes (embora alguns dissessem que eles eram azuis). Também é verdade que, como jornalista, ele algumas vezes escreveu crônicas sobre os bailes e banquetes da alta sociedade de Havana, portanto aquele substantivo "fiesta", no início, poderia ser um eco deles (de toda forma, haverá ecos desse tipo, mais inequívocos, logo à frente: "la condesa de Fernandina", no verso 65, e "la marquesa Polavieja", no verso 116, foram de fato senhoras da alta sociedade, sobre as quais Casal escreveu com os mais eloquentes detalhes). ${ }^{5}$ Também se dizia que ele apreciava japoneries e chinoiseries, o que é também evidente em seus escritos: daí a máscara japonesa no verso 19 (um de seus amigos relata que ele tinha uma "horrible máscara asiática" na parede de seu quarto [cf. Sanguily, 1963, p.30]) e o "dragón de hilos de oro" no verso 20 (provavelmente uma besta, representada numa sombrinha, ou num quimono seu, como os "dragones hechos con áureos hilos" no quimono de sua amiga María Cay, que ele retratou no poema "Kakemono"). Casal também escreveu crítica de teatro e de música de todos os tipos, do vaudeville à ópera: daí a menção, no verso 22, a "el Teatro Tacón", um teatro real de Havana que o poeta costumava frequentar. E aquela "tos alegre" no verso 18 , tão incongruente à primeira vista, é a primeira numa longa e diversa série de alusões à sua fatal tuberculose. A última dessas alusões, aparentemente ainda mais incongruente, embora factual, aparece no fim do poema, no verso 183: "alcanzaste a morir muerto de risa". (Casal morreu de uma súbita e maciça hemorragia pulmonar provocada por um acesso de riso, quando um amigo the contava uma piada durante um jantar.)

Como já dito, porém, esses detalhes "reais" são apenas gradualmente mesclados à textura do poema - uma textura densamente cosida, que termina por reinscrever aqueles detalhes todos em uma outra ordem. E tal "mescla" vai ainda mais fundo e mais longe do que sugerido até aqui. Informações provindas de dois ensaios de Lezama permitem verificar até onde tal mescla ocorre na segunda estrofe, que se abre (v.13-18) com variações das apóstrofes iniciais, que agora conduzem o sujeito a um espaço caracterizado por uma gama de coisas e criaturas bastante peculiar:

Déjenlo que acompañe sin hablar, permitidle, blandamente, que se vuelva

hacia el frutero donde están los osos con el plato de nieve, o el reno de la escribanía, con su manilla de ámbar por la espalda... 
Cinco anos depois de escrever esse poema, em 1968, em um ensaio autobiográfico intitulado "Confluencias", Lezama Lima (1970, p.455-6) fala de um momento dramático de sua própria adolescência, quando, diante dele, sua avó retirou, de um enorme guarda-roupa de sua casa no Prado, em Havana, uma grande quantidade de relíquias de família e mementos, cuja visão repentinamente reacende nele uma miríade de lembranças infantis:

Abi estaban el smoking de mi abuelo, con el cual había muerto mi tío Andresito, los trajes con los que mi abuela habia asistido a las bodas de sus hijas. Estaba también alli una desmesurada escribanía con pozuelo para la tinta y unos renos de plata labrada, y sobre la escribanía una manilla de ámbar muy usada en el XVIII y XIX, para rascarse. Esa ingenua oleada reminiscente pasa a la segunda estrofa de mi obra Oda a Julián del Casal [donde], para sugerir el título de una de sus obras aludo al reno de la escribania y a una manilla de ámbar por la espalda. A veces pienso con deleite que en el día de las despedidas, ese escaparate titánico volverá a abrirse para mí. Oímos de nuevo:

Déjenlo que acompañe sin hablar, permitidle, blandamente, que se vuelva hacia el frutero donde están los osos con el plato de nieve, o el reno de la escribania, con su manilla de ámbar.

Era un ruego que hacia por Casal y por mi.

Há vários detalhes que vale a pena comentar nessa extraordinária revelação, e retornaremos em seguida a alguns deles. Por ora, entretanto, notemos apenas que, para caracterizar o sujeito de seu poema, Lezama lhe transferiu detalhes de sua própria vida.

Temos também evidências que apontam para outra transferência, do mesmo tipo, em outra passagem que aparece um pouco depois, na mesma estrofe (v.22-27):

... [camina] hasta la Concha de oro del Teatro Tacón, donde rígida la corista colocará

sus flores en el pico del cisne,

como la mulata de los tres gritos en el vodevil

y los neoclásicos senos martillados por la pedantería de Clesinger...

Muitos anos antes de escrever esse poema, em 1941, Lezama Lima (1953, p.236) publicou um breve ensaio, intitulado "Parejas infieles", sobre o tema dos poetas oitocentistas franceses que frequentavam os camarins das atrizes, e é lá que encontramos esta passagem sobre Baudelaire:

Las dos mujeres que rondan a Baudelaire le colocan en deliciosos antipodas: Jeanne Duval, mulata nerviosa, cuyo papel en los vodevils reduciase a asomar el rostro $y$ dar tres gritos acuchillados, le acerca al XIX de Saint Pierre. Es la querida 
delgada de Baudelaire y podia haber sido conocida a la salida del camerino. Pero Madame Sabatier le lleva al XVIII. ¿Acaso no la habia conocido Baudelaire en el taller del escultor Clésinger, tan neoclásico que su cámara de trabajo parecía tanto un mausoleo como un camerino?

Nesse caso, as transferências foram tomadas da vida de Baudelaire, cujo nome, é claro, aparecerá ainda várias vezes no poema, em comparações hipotéticas com o sujeito. Note-se como os dois tipos de espaço evocados pelos dois conjuntos de transferências contrastam um com o outro: de um lado, detalhes até agora possivelmente ignorados da vida privada e familiar de Lezama; de outro, detalhes obscuros e ainda assim factuais, concernentes a duas amantes de Baudelaire e suas outras conexões artísticas. Então aqui, nessa estrofe em que o sujeito que emerge começa a ser caracterizado por alguns poucos detalhes da vida de Casal, há, ao mesmo tempo, e quase imperceptivelmente mesclados a eles, detalhes das vidas de dois outros poetas, o que cria uma espécie de vida compósita. ${ }^{6}$

É claro que informações desse tipo, ainda quando provenham do próprio autor, não nos eximem da tarefa de ler o texto. Precisamos ainda distinguir o que dizem ou deixam de dizer as passagens no poema. Particularmente interessante, nesse sentido, é o caso dos objetos e animais listados nos versos 13-18: fruteira, ursos, prato de neve, renas, escrivaninha, um cabo para coçar as costas. Lezama diz que esses eram bibelôs, mementos familiares, incluídos "para sugerir o título de uma das obras [de Casal]". De fato, o título de uma das antologias poéticas de Casal é Nieve. Mas uma enumeração de mementos sugere um certo tipo de espaço doméstico que os dois poetas cubanos, ainda quando separados por duas gerações, poderiam ter compartilhado, e seguramente esse é o efeito mais inclusivo buscado pelo poema. (E tais objetos não são de pouca importância: o espaço doméstico, por definição, contém sempre mementos dos mortos, não importa quão insignificantes eles possam parecer aos outros, e é precisamente tal fato que o ensaio de Lezama dramatiza. $\left.{ }^{7}\right)$ Resta aqui, é claro, a questão de como um leitor, ignorante daquelas revelações de Lezama, leria uma lista tão heterogênea.

Tomados em conjunto, uma fruteira, uma prancha de escrever e um cabo para coçar as costas compõem de fato uma reconhecível série doméstica, mas como aquele leitor encaixaria os ursos, as renas e a neve? E ele os tomaria como "reais" ou, como os define o ensaio, como representações, figurinos, pequenos e raros objetos? Aí aparece um tipo de perplexidade e indeterminação que se pode encontrar em diversas passagens do poema. De fato, é também desse tipo a combinação de ameixeira e abacaxi que observávamos páginas atrás, e que agora, desta perspectiva, parece conceber-se como uma outra espécie de bibelô.

Tudo isso, já se terá notado, desenvolve-se ainda a partir da questão daquilo que pode ou não ser reconhecível. Ambas as passagens que examinamos fazem pensar no tipo de leitor ideal que elas pressupõem. Para colocá-lo de outra forma: que tipo de cultura literária - e com que tipo de cânon poético - poderia 
reconhecer alusões assim íntimas às vidas e à poesia de Baudelaire, de Casal e de Lezama, tudo ao mesmo tempo? Pergunto-me se todo o poema não pressupõe o advento de uma utopia literária desse tipo.

O próximo atributo a discutir é a maneira como no poema se utilizam certos tempos e modalidades verbais, de forma a criar certa perspectiva temporal. Trata-se, é claro, de um tema muito complexo, e limito-me aqui a uns poucos exemplos apenas.

No início deste artigo, quando me referi às apóstrofes, sugeri que o verso 63, na abertura da quinta estrofe, marca um ponto de viragem retórico, justamente porque é ali que aquele "tu" singular começa a ser apostrofado. Esse é um ponto de viragem também sob outro aspecto, porque ali, também pela primeira vez, a voz do poema diz que o sujeito $f e z$ algo, uma afirmação feita no pretérito, como parte de uma narrativa contada no passado: "Las formas en que utilizaste tus disfraces...".

Até este momento, as ações do sujeito foram narradas apenas no futuro ou no presente, como se ainda se desdobrassem desde aquele ato inicial da fala, quando as apóstrofes convocavam o sujeito a ingressar no "agora" do poema. Mas aqui, à medida que a voz lírica começa a falar para o sujeito, ela também lhe relata o que ele $f e z$ no passado, presumivelmente no passado de sua própria vida. Esse é o início de uma extensa rede de segmentos narrativos que têm como protagonista o sujeito, e que ocupam grande parte do que resta do poema, desdobrando-se em diferentes dimensões temporais, para trás e para frente, e mesmo, por assim dizer, para o lado. Afinal, note-se também que aquele primeiro pretérito é seguido, na mesma linha narrativa, por um pretérito mais-queperfeito composto do subjuntivo (no verso 64, “...hubieran logrado influenciar a Baudelaive"), destarte criando um linha narrativa alternativa, propondo até mesmo uma versão alternativa da história, na qual as influências mundiais correm em direções diferentes.

É interessante notar como, um pouco antes daquele ponto de viragem, a utilização de certas formas verbais traz, implicitamente, o sujeito do poema mais decididamente para dentro do texto, como uma presença efetiva, preparando assim o papel mais ativo que ele desempenhará como protagonista.

$\mathrm{Na}$ quarta estrofe (começando no verso 44), toda ela narrada ainda no presente, encontramos, com especial riqueza de detalhes, uma reprise daquela visita à corista, relatada na segunda estrofe (as flores dadas de presente). (Note-se, aliás, com que frequência o sujeito do poema é caracterizado em termos de $s_{0}$ ciabilidade: visitas, cumprimentos e, especialmente, presentes.) O motivo do frio que notamos antes é aqui repetido insistentemente: o adjetivo "frío" ocorre sete vezes apenas nessa estrofe, referido às mãos do sujeito e a outras coisas próximas que são mencionadas, produzindo um tipo de efeito de contágio, que em parte é uma reiteração dos sintomas físicos do sujeito doente, introduzidos antes em termos de sua tosse, como vimos - e, de fato, também a tosse é recorrente aqui. 


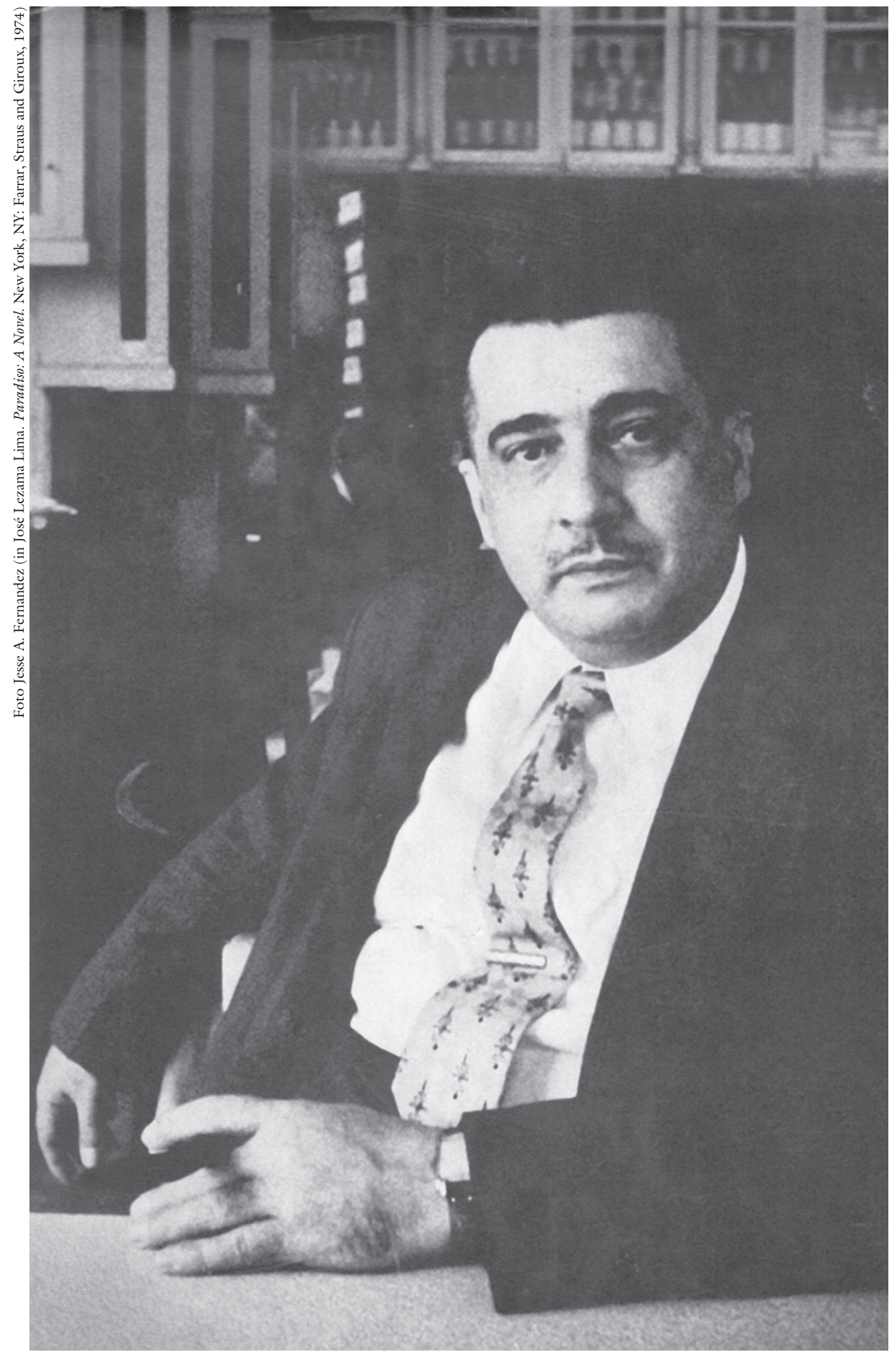

O poeta, ensaista e novelista cubano José Lezama Lima (1910-1976). 


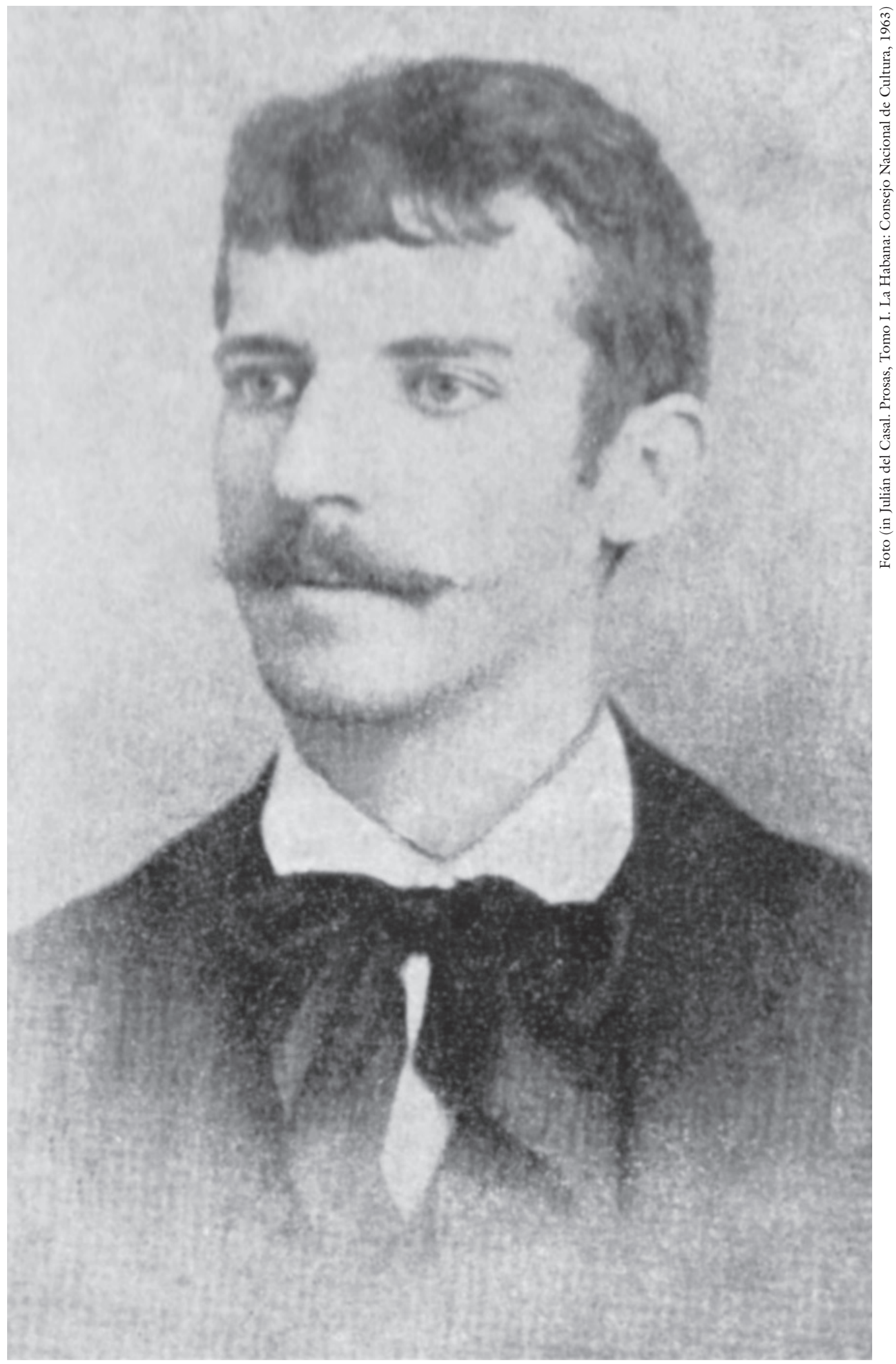

Julián del Casal (1863-1893), poeta e escritor cubano. 
Mãos frias que, embora frias, podem dar mais vida ("avivar") às coisas que tocam. Aqui, novamente, podemos ver aquele sentido a que me referia em relação à primeira estrofe do poema, isto é, a um só tempo um sentido forte de interação física e de instabilidade centrífuga. A cena das flores presenteadas à corista é expandida: um estranho terceiro personagem é introduzido, o manequim, uma efígie inerte que, entretanto, experimenta estranhos traumas em algum estranho cenário, não mais simplesmente um teatro, mas algo que inclui um penhasco, uma praia. E estranhas aranhas também, igualmente trazidas de uma referência anterior - do verso 33, "el brillo de las arañas verdes" - e também trabalhadas pelas mãos do sujeito. Mas seriam elas, de fato, "aranhas"? A palavra "araña" pode também significar, em espanhol corrente, "candelabro", e acontece que em suas crônicas Casal comentava com frequência a iluminação, fosse a gás ou elétrica, nas casas ou em espaços públicos, usando muitas vezes precisamente aquela palavra. Repetidas vezes o poema enlaça tal vocábulo à sua textura, como parte de uma abundante zoologia fantástica, ao mesmo tempo alterando os qualificativos que ela carrega, mas jamais a ponto de que possamos determinar precisamente qual de seus sentidos predomina.

Aqui, quando a quarta estrofe se encerra, a inclusão de duas formas verbais que não haviam ainda sido utilizadas ratifica a presença ativa do sujeito no poema. É o caso, nos versos 55 e 57, da repetição do aviso "cuidado" (não, a rigor, uma forma verbal, mas ainda assim um tipo de imperativo, como se fosse dito "tenham cuidado"), como se o leitor fosse avisado de atividades futuras - e de grandes poderes - do sujeito: "cuidado, sus manos pueden avivar..." e "cuidado, él sigue oyendo...", esta última utilizando a outra forma verbal: o gerúndio como presente contínuo, também repetido quase imediatamente, em "su tos alegre signe ordenando...". As duas formas verbais representam um posicionamento da voz lírica, como se ela se aproximasse do leitor, envolvendo-o num agora compartilhado, que parece incluir o tempo mesmo da leitura. Mais tarde, nas quatro últimas estrofes, depois ainda da introdução de um pretérito narrativo, a voz narrativa vai intensificar esse efeito de inclusão dramática, por meio do uso de dêiticos como "ahora" e "ya".

Trato agora do último dos atributos do poema que importa identificar: suas alusões míticas. Vimos há pouco, no fecho da quarta estrofe, como, daquela estranha interação de mãos, flores, corista, manequim, penhasco, praia, lustres aracnídeos etc., o sujeito emerge como alguém que agora age num amplo cenário natural: "la propia tierra maternal", "espacio coralino", "nuestra crecida vegetal", agindo naquele cenário, precisamente, como uma força reguladora que se sustém até mesmo agora enquanto falamos (v.60-62):

Su tos alegre sigue ordenando el ritmo

de nuestra crecida vegetal,

al extenderse dormido. 
Ao anunciar o poder do sujeito de governar "el ritmo/ de nuestra crecida vegetal", a frase prenuncia o seu ressurgimento mais à frente, nas três últimas estrofes, como um ator em um contexto explicitamente mítico. Nos versos 151157, lemos:

Los frascos de perfume que entreabriste,

ahora te hacen salir de ellos como un homúnculo,

ente de imagen creado por la evaporación,

corteza del árbol donde Adonai

buyó del jabali para alcanzar

la resurrección de las estaciones.

E no verso 164, último da mesma estrofe, também lemos: “...llevaste nuestra luciérnaga verde al valle de Proserpina".

As duas passagens evocam, sob nomes variados, conhecidos protagonistas da mitologia grega: "Proserpina" é o nome latino de "Perséfone", rainha do Tártaro, o mundo dos mortos, e o nome hebraico "Adonai" substitui "Adonis", o jovem amado por Perséfone e Afrodite, a quem é permitido, após sua morte e descida aos infernos, que regresse periodicamente ao mundo dos vivos, com seu movimento de ida e vinda marcando então os ciclos naturais do inverno (morte) e da primavera (renascimento). Se o uso de "Proserpina" no lugar de "Perséfone" ainda se refere à mesma deidade grega, "Adonai" por "Adonis" é uma questão diversa, porque o hebraico "Adonai" é um apelativo para nada menos que o Deus do judaísmo e da cristandade (e às vezes, neste último caso, para o próprio Cristo). Portanto, quando o poema insere "Adonai" naquela passagem que evoca o mito grego, há um deslocamento em mais de um sentido. Afinal, não se diz de fato que o sujeito é Adonai/Adonis. Adonis nasceu da casca da árvore na qual sua mãe havia sido transformada, enquanto o nosso sujeito é considerado uma espécie de fragrância versátil, como que emanando (mas apenas em parte) daquela casca. Após tal inserção, virá ainda outro deslocamento: um pouco depois, nos versos 169-170, ressurge o nome "Adonai", parecendo agora regressar a seu sentido tradicional, com o sujeito assumindo um papel diferente:

Pues todo poeta se apresura sin saberlo

para cumplir las órdenes indescifrables de Adonai.

A maneira como são usados esses nomes é apenas uma das muitas indicações de como o poema mescla e reconfigura paradigmas míticos.

O mito de Adonis (como o da própria Perséfone) tradicionalmente marca o retorno da verdura ao mundo dos vivos. Mas o sujeito do poema de Lezama é seguidamente referido como fazendo o movimento inverso, tomando consigo algo verde para levá-lo ao mundo dos mortos, não apenas no verso citado há pouco - "llevaste nuestra luciérnaga verde al valle de Proserpina" -, mas também nas três seguintes passagens, que se destacam nas duas últimas estrofes: 
La misión que te fue encomendada, descender a las profundidades con nuestra chispa verde... (v.165-166)

...quisiste llevar el verde de tus ojos verdes

a la terraza de los dormidos invisibles (v.172-173)

...la chispa con la que descendiste

al lento oscuro de la terraza helada (v.190-191)

À luz dessas passagens, vê-se mais claramente algo que já havíamos notado antes: "verde", no poema, desdobra um conjunto de conotações que vai bem além da vida e da vegetação. Vê-se também que, embora o sujeito do poema guarde alguns traços de Adonis/Adonai, ele é ainda uma figura compósita cujas características evocam também outros heróis míticos. A centelha, tomada pela nossa salvação, evoca Prometeu. Levar algo vital para os mortos, que têm suas necessidades e devem também ser sustentados, evoca Osíris, o deus egípcio que vence a morte e renasce para desempenhar tal função. Nos versos 137-139, lêse:

Eres el huevo de cristal,

donde el amarillo está reemplazado

por el verde errante de tus ojos verdes.

Tais versos parecem enxertar o errante verde do sujeito no ovo do antigo orfismo grego. Resta daí, portanto, que a economia de vida e morte desse poema é particularmente rica e híbrida, com um alcance que aqui mal começamos a medir.

Para levar um pouco adiante tal economia, há três pontos que deveriam ser tomados em conta: (1) as comparações do sujeito com Baudelaire, (2) o papel desempenhado pelos "dormidos de la terraza" e (3) aquele "quitasol de un inmenso Eros" que se diz que o sujeito abre "aqui y all”", nos versos 174-176.

O sujeito não é comparado a Baudelaire como um fazedor de poemas. Antes de mais nada, são os seus disfarces que poderiam ter "influenciado" o poeta francês (leiam-se os versos 63 e 78-81) e, então, a vida e a morte do sujeito têm a mesma "qualidade" que em Baudelaire, e poderiam também tê-lo influenciado (v.83-84, 143-144, 179-181 e 184). Como entender isso? Como podem os disfarces colocar-se no mesmo nível de importância que a vida e a morte? É verdade que os dois sujeitos históricos, Casal e Baudelaire, foram dândis, posaram com estardalhaço, deliciando-se em vestir-se e revestir-se dos mais ardentes garbos, e ornamentos. Mas por meio de sucessivas recontextualizações, o poema de Lezama empresta à palavra "disfraces" um alcance de significações muito maior que o que ela normalmente tem (da mesma forma como notamos isso ocorrendo com outras palavras). No momento em que aparece na quinta estrofe, a palavra “disfraces" já parece abranger todas as estranhas manifestações textuais por meio das quais, até ali, o sujeito atravessou o espaço do poema: seus múltiplos traços, 
incluindo os sintomas corporais que apontam para seu sofrimento, sua morte. E é a dignidade e intensidade de sua posição, sua postura diante da vida e da morte - sua paixão, no sentido mais extremo do termo - que o tornam passível de comparação com Baudelaire. O que não quer dizer que a poesia do sujeito histórico Casal seja ignorada no poema. Os versos 168 e 186 repetem um verso de seu poema "Nihilismo": "Ansias de aniquilarme sólo siento". E os versos 104-107 contêm alusões precisas a pelo menos outros três de seus poemas ("Las oceánidas", "Venus Anadyomena" e "Marina"):

...pues entre la medianoche y el despertar,

hacias tus injertos de azalea con araña fría,

que engendraban los sollozos de la Venus Anadyomena

y el brazalete robado por el pico del alción.

Note-se a maneira de figurar a atividade criadora do sujeito: um enxerto de azaleias em aranhas, que engendra os soluços de uma deusa e uma pulseira roubada por uma ave. Daí o uso que fiz do termo "híbrido", quando me referi às figurações poéticas de Lezama: aqui, o poema está dando nome a seu próprio procedimento. Voltaremos a esses versos em seguida.

Quem são aqueles “dormidos” que reaparecem ao longo do poema, alocados em sua "terraza"? Uma coisa é certa: a despeito daquela estratégica insistência, sempre em profunda conexão com o sujeito, o poema não nos dirá exatamente quem são eles. O que o poema exatamente faz, quase ao fim (v.172173, 190-191), é igualar a "terraza belada" ao mundo dos mortos a que o sujeito leva o seu verde. Mas o "sono” desses “dormidos de la terraza” não é uma metáfora ordinária para a "morte", porque o seu é um sono singularmente ativo: eles circulam (v.126-127) e ainda respondem solertemente aos cuidados do sujeito (v.75-76). Localizam-se eles na morte, ou em ambos, vida e morte? Será o seu "sono" um estado de insensibilidade hostil, como aquela dos néscios, de acordo com certas crenças gnósticas? Note-se agora como eles são levados àquela notável sequência com a qual a penúltima estrofe caminha para um fecho (v.172-176):

\section{...quisiste llevar el verde de tus ojos verdes}

a la terraza de los dormidos invisibles.

Por eso aqui y alli, con los excavadores de la identidad,

entre los reseñadores y los sombrosos,

abres el quitasol de un inmenso Eros.

Quem são os "excavadores", "reseñadores" e "sombrosos”? Não são designações propriamente gentis. Dirão elas respeito aos “dormidos”? Esse "aqui y allî é muito impressionante. Em nenhum outro lugar no poema a voz lírica fala desde um "aqui". Nesse caso, “alli” é claramente "la terraza de los dormidos", portanto "aqui" deve ser o bic et nunc da enunciação do poema, isto é, o mundo dos vivos. Mas, se no mundo dos mortos nem todos estão realmente mortos, 
então no mundo dos vivos nem todos são realmente vivos. E aquele “por eso" é também inusitado: como consequência categoricamente afirmada de sua missão no mundo dos mortos - e agindo em ambos os reinos, agora, no tempo presente -, o sujeito abre esse igualmente inaudito "quitasol de un inmenso Eros".

Eis então que outra figura mitológica é nomeada, um mensageiro do amor, não a portar arco e flecha, ou a lança com que Eros é normalmente representado, mas aquela cobertura protetora que o adjetivo "inmenso" parece também qualificar metonimicamente: um enorme e acolhedor "quitasol". Leitores familiares com um conto de Casal, escrito alguns meses antes de sua morte, "El amante de las torturas", recordarão aqui aquela "red inmensa, tramada de hilos de seda [...], mostrando en el centro, a manera de roseta, un quitasol japonés" (Casal, 1963, p.236), com a qual o protagonista havia decorado o teto de seu quarto. Anteriormente, sugeri que os "disfraces" do sujeito poderiam ser entendidos como suas múltiplas manifestações ao longo do poema. Da mesma forma, poderia sugerir aqui que este "quitasol de un inmenso Eros" seja tomado como figurando não apenas o escopo, mas também a natureza mesma das conexões que o sujeito estabelece por meio do espaço do poema. Os poemas de Casal, aludidos na passagem já citada (v.105-107) - "Las oceánidas", "Venus Anadyomena”, "Marina” -, são todos intensamente, polimorficamente eróticos, em seus desenhos de corpos em paisagens líquidas: o corpo martirizado de Prometeu, o corpo de Vênus emergindo das ondas, o corpo flutuante de uma mulher morta, cuja pulseira dourada o bico de uma ave marinha arranca.

Embora a última estrofe do poema de Lezama seja admirável - na amplitude coral com a qual ela reinstaura e recombina, ajustando-os, motivos e apelos anteriores -, parece-me, contudo, que seus versos mais comovedores são precisamente aqueles com os quais se encerra a penúltima estrofe, isto é, os versos que tornam mais explícita a conexão da voz lírica - e a partir daí também a conexão do leitor - com o sujeito que ela tão largamente convocou:

Nuestro escandaloso cariño te persigue

y por eso sonries entre los muertos.

Belíssimos versos, pronunciados certamente - e a serem pronunciados de novo - com um correspondente sorriso. ${ }^{8}$

Notas

1 Traduzido do inglês por Pedro Meira Monteiro. Segue o poema de Lezama Lima, "Oda a Julián del Casal":

Déjenlo, verdeante, que se vuelva; permitidle que salga de la fiesta a la terraza donde están dormidos. A los dormidos los cuidará quejoso, fijándose como se agrupa la mañana helada.
La errante chispa de su verde errante, trazará circulos frente a los dormidos de la terraza, la seda de su solapa escurre el agua repasada del tritón y otro tritón sobre su espalda en polvo. (10) 
Dejadlo que se vuelva, mitad ciruelo

y mitad piña laqueada por la frente.

Déjenlo que acompañe sin hablar, permitidle, blandamente, que se vuelva hacia el frutero donde están los osos con el plato de nieve, o el reno de la escribania, con su manilla de ámbar por la espalda. Su tos alegre espolvorea la máscara de combatientes japoneses. Dentro de un dragón de hilos de oro, (20) camina ligero con los pedidos de la lluvia, hasta la Concha de oro del Teatro Tacón, donde rígida la corista colocará sus flores en el pico del cisne, como la mulata de los tres gritos en el vodevil y los neoclásicos senos martillados por la pedantería de Clesinger. Todo pasó cuando ya fue pasado, pero también pasó la aurora con su punto de nieve.

Si lo tocan, chirrian sus arenas; (30) si lo mueven, el arco iris rompe sus cenizas. Inmóvil en la brisa, sujetado por el brillo de las arañas verdes.

Es un vaho que se dobla en las ventanas.

Trae la carta funeral del ópalo.

Trae el pañuelo de opopónax y agua quejumbrosa a la visita sin sentarse apenas, con muchos quédese, quédese, que se acercan para llorar en su sonido (40) como los sillones de mimbre de las ruinas del ingenio, en cuyas ruinas se quedó para siempre el ancla de su infantil chaqueta marinera.

Pregunta y no espera la respuesta, lo tiran de la manga con trifolias de ceniza. Están frías las ornadas florecillas. Frías están sus manos que no acaban, aprieta las manos con sus manos frías. Sus manos no están frías, frío es el sudor que lo detiene en su visita a la corista. (50) Le entrega las flores y el maniquí se rompe en las baldosas rotas del acantilado. Sus manos frías avivan las arañas ebrias, que van a deglutir el maniqui playero. Cuidado, sus manos pueden avivar la araña fría y el maniqui de las coristas. Cuidado, él sigue oyendo cómo evapora la propia tierra maternal, compás para el espacio coralino.

Su tos alegre sigue ordenando el ritmo (60) de nuestra crecida vegetal, al extenderse dormido. Las formas en que utilizaste tus disfraces, hubieran logrado influenciar a Baudelaire. El espejo que unió a la condesa de Fernandina con Napoleón Tercero, no te arrancó las mismas flores que le llevaste a la corista, pues alli viste el aleph negro en lo alto del surtidor. Cronista de la boda de Luna de Copas con la Sota de Bastos, tuviste que brindar (70) con champagne gelé por los sudores fríos de tu medianoche de agonizante.

Los dormidos en la terraza, que tú tan sólo los tocabas quejumbrosamente, escupian sobre el tazón que tú le llevabas a los cisnes.

No respetaban que tú le habias encristalado la terraza y llevado el menguante de la liebre al espejo.

Tus disfraces, como el almirante samurai, que tapó la escuadra enemiga con un abanico, o el monje que no sabe qué espera en El Escorial,(80) hubieran producido otro escalofrío en Baudelaire. Sus sombrios rasguños, exagramas chinos en tu sangre, se igualaban con la influencia que tu vida hubiera dejado en Baudelaire, como lograste alucinar al Sileno con ojos de sapo y diamante frontal.

Los fantasmas resinosos, los gatos que dormian en el bolsillo de tu chaleco estrellado, se embriagaban con tus ojos verdes.

Desde entonces, el mayor gato, el peligroso genuflexo,(90) no ha vuelto a ser acariciado.

Cuando el gato termine la madeja, le gustará jugar con tu cerquillo, como las estrías de la tortuga nos dan la boja precisa de nuestro fin. Tu calidad cariciosa, que colocaba un sofá de mimbre en una estampa japonesa, el sofá volante, como los paños de fondo de los relatos hagiográficos, que vino para ayudarte a morir. (100) El mail coach con trompetas, acudido para despertar a los dormidos de la terraza, rompia tu escaso sueño en la madrugada, pues entre la medianoche y el despertar hacias tus injertos de azalea con araña fría, que engendraban los sollozos de la Venus Anadyomena y el brazalete robado por el pico del alción. Sea maldito el que se equivoque y te quiera ofender, riéndose de tus disfraces o de lo que escribiste en La Caricatura, (110) con tan buena suerte que nadie ha podido encontrar lo que escribiste para burlarte y poder comprar la máscara japonesa. Cómo se deben haber reido los ángeles, cuando saludabas estupefacto a la marquesa Polavieja, que avanzaba hacia ti para palmearte frente al espejo. Qué horror, debes haber soltado un lagarto 
sobre la trifolia de una taza de té.

Haces después de muerto (120)

las mismas iniciales, ahora

en el mojado escudo de cobre de la noche,

que comprobaban al tacto

la trigueñita de los doce años

y el padre enloquecido colgado de un árbol.

Sigues trazando circulos

en torno a los que se pasean por la terraza,

la chispa errante de tu errante verde.

Todos sabemos ya que no era tuyo

el falso terciopelo de la magia verde, (130)

los pasos contados sobre alfombras,

la daga que divide las barajas,

para unirlas de nuevo con tizne de cisnes.

No era tampoco tuya la separación,

que la tribu de malvados te atribuye,

entre el espejo y el lago.

Eres el huevo de cristal,

donde el amarillo está reemplazado

por el verde errante de tus ojos verdes.

Invencionaste un color solemne, (140)

guardamos ese verde entre dos hojas.

El verde de la muerte.

\section{Ninguna estrofa de Baudelaire,}

puede igualar el sonido de tu tos alegre.

Podemos retocar,

pero en definitiva lo que queda,

es la forma en que hemos sido retocados.

¿Por quién?

Respondan la chispa errante de tus ojos verdes

$y$ el sonido de tu tos alegre. (150)

Los frascos de perfume que entreabriste,

ahora te hacen salir de ellos como un homúnculo,

ente de imagen creado por la evaporación,

corteza del árbol donde Adonai

buyó del jabali para alcanzar

la resurrección de las estaciones.
El frío de tus manos,

es nuestra franja de la muerte,

tiene la misma hilacha de la manga

verde oro del disfraz para morir, (160)

es el frio de todas nuestras manos.

A pesar del frío de nuestra inicial timidez

$y$ del sorprendido en nuestro miedo final,

llevaste nuestra luciérnaga verde al valle de Proserpina.

La misión que te fue encomendada,

descender a las profundidades con nuestra chispa verde,

la quisiste cumplir de inmediato y por eso escribiste:

ansias de aniquilarme sólo siento.

Pues todo poeta se apresura sin saberlo

para cumplir las órdenes indescifrables de Adonai. (170)

Ahora ya sabemos el esplendor de esa sentencia tuya,

quisiste llevar el verde de tus ojos verdes

a la terraza de los dormidos invisibles.

Por eso aqui y alli, con los excavadores de la identidad,

entre los reseñadores y los sombrosos,

abres el quitasol de un inmenso Eros.

Nuestro escandaloso cariño te persigue

y por eso sonries entre los muertos.

La muerte de Baudelaire, balbuceando

incesantemente: Sagrado nombre, Sagrado nombre, (180)

tiene la misma calidad de tu muerte,

pues habiendo vivido como un delfín muerto de sueño,

alcanzaste a morir muerto de risa.

Tu muerte podía haber influenciado a Baudelaire.

Aquel que entre nosotros dijo:

ansias de aniquilarme sólo siento,

fue tapado por la risa como una lava.

En esas ruinas, cubierto por la muerte,

ahora reaparece el cigarrillo que entre tus dedos se quemaba,

la chispa con la que descendiste (190)

al lento oscuro de la terraza helada.

Permitid que se vuelva, ya nos mira,

qué compañia la chispa errante de su errante verde, mitad ciruelo y mitad piña laqueada por la frente.

2 O poema foi pela primeira vez publicado na Revista de la Biblioteca Nacional "José Martí" (Havana, año V, n.1-4, p.5-10, 1963). O poema é datado de "Junio 1963".

$3 \mathrm{O}$ texto seria mais tarde incluído na primeira antologia de ensaios de Lezama Lima (1953, p.62-97).

4 Trata-se de uma série de palestras, primeiro publicadas em Havana em 1957 pelo Insituto de Cultura del Ministerio de Educación. O leitor brasileiro deve consultar a excelente tradução de Irlemar Chiampi, com sua extensa introdução crítica e notas (cf. Lezama Lima, 1988).

5 Nos próprios retratos que escreveu dela, contudo, Casal não chamou Concepción Castrillo de Polavieja "marquesa", mas sim "la bella generala", "la hermosa generala" (cf. Casal, 1964, p.14, 48-50, 52-54). Seu marido, Camilo García de Polavieja y del Castillo (1838-1914), capitão-general da colônia entre 1890 e 1891, recebeu o título 
de marquês apenas em 1895, após a morte de Casal. Casal (1963, p.135-6; 1964, p.43-4, 46-8) efusivamente evoca María Serafina de Montalvo y Cárdenas, condessa de Fernandina.

6 Note-se como a frase “[camina] hasta la Concha de Oro del Teatro Tacón” também rememora um tempo anterior à vida de Casal. "La Concha de Oro" foi uma orquestra famosa no início do século XIX em Havana, liderada pelo conhecido violinista cubano Claudio Brindis de Salas (1800-1872) (cf. Orovio, 2004, p.35).

7 Procuro aqui ecoar partes do terceiro capítulo ("What Is a House?") do admirável livro de Robert Pogue Harrison (2003), intitulado The Dominion of the Dead, o qual, como pretende sugerir a primeira de minhas epígrafes, influenciou significativamente minha visão do poema de Lezama. Ver, em especial, sua observação sobre "aqueles variados objetos deixados, mementos e retratos nos quais, e através dos quais, fantasmas domésticos tipicamente se fazem presentes no tradicional espaço da casa" (ibidem, p.43).

8 Ao longo dos últimos quinze anos, aproximadamente, a vida e a obra de Casal têm sido examinadas da perspectiva dos gay studies e da teoria queer. Ver, em particular, os excelentes trabalhos de dois críticos cubanos exilados: Oscar Montero (s. d., 1993, 1993) e Francisco Morán (2008).

\section{Referências}

CASAL, J. del. Prosas I. Havana: Consejo Nacional de Cultura, 1963.

Prosas III. Havana: Consejo Nacional de Cultura, 1964.

DARÍO, R. Julián del Casal (1894). In: __. Obras completas, I. Madrid: Afrodisio Aguado, 1950.

HARRISON, R. P. The Dominion of the Dead. Chicago, Il: Chicago University Press, 2003.

LEZAMA LIMA, J. Analecta del reloj. Havana: Orígenes, 1953.

. La cantidad hechizada. Havana: Uneac, 1970.

. A expressão americana. São Paulo: Brasiliense, 1988.

MONTERO, O. Casal and Maceo: Art, War and Race in Colonial Havana. s. d. Disponível em: <http:// www.lehman.cuny.edu/ ciberletras/vlnlens_07.htm>. dopi, 1993.

Erotismo y representación en Julián del Casal. Amsterdam, Atlanta, GA: Ro-

. Julián del Casal and the Queers of Havana. In: BERGMANN, E. L.; SMITH, P. J. (Ed.) ¿Entiendes? Queer Readings, Hispanic Writings. Durham, NC: Duke University Press, 1995.

MORÁN, F. Julián del Casal, o, los pliegues del deseo. Madrid: Verbum, 2008.

OROVIO, H. Cuban Music from A to Z. Durham: Duke University Press, 2004.

SANGUILY, M. Corona fúnebre. In: CASAL, J. del. Prosas, I. Havana: Consejo Nacional de Cultura, 1963. 
RESUMO - Este comentário ao notável poema de Lezama Lima (1910-1976), “Oda a Julián del Casal", detém-se sobre o modo como seis de seus principais atributos textuais - suas apóstrofes, os motivos verbais recorrentes, a obscuridade, os motivos históricos reconhecíveis, seus tempos verbais, bem como suas alusões míticas - interagem de forma a produzir um efeito retórico determinado. Julián del Casal (Cuba, 1863-1893) é atualmente considerado um dos mais importantes poetas hispano-americanos de seu tempo. Lezama, por seu turno, compôs seu poema em 1963, durante a celebração do centenário de nascimento de Casal.

Palavras-Chave: José Lezama Lima, Julián del Casal, Poesia latino-americana.

ABSTRACT - This commentary on one of José Lezama Lima's (1910-1976) most memorable poems, "Oda a Julián del Casal", focuses on how six of its textual features apostrophes, recurrent verbal motifs, obscurity, recognizability, verb tenses and moods, and mythical allusions - interact to produce an overall rhetorical effect. Julián del Casal (Cuba, 1863-1893) is now considered one of the most important Hispanic American poets of his historical moment. Lezama composed his poem in 1963 during the celebration of the centenary of Casal's birth.

KEYWORDS: José Lezama Lima, Julián del Casal, Latin American poetry.

James Irby é professor emérito de Literatura Latino-Americana da Princeton University, nos Estados Unidos. Foi um dos primeiros tradutores de Borges ao inglês. De Lezama Lima, traduziu diversos textos, em poesia e prosa. Escreve regularmente na revista eletrônica La Habana Elegante, onde foi publicada uma primeira versão do presente ensaio ("Speaking to the Living and the Dead: Lezama's Ode to Casal"). @ - irby@Princeton.EDU

Traduzido por Pedro Meira Monteiro. O original em inglês - "Speaking to the Living and the Dead: Lezama's Ode to Casal" - encontra-se à disposição do leitor no IEAUSP para eventual consulta.

Recebido em 16.6.2010 e aceito em 22.6.2010. 